\title{
Success Criteria for Automation and Robotics in Industrialised Building System (IBS)
}

Mohd Najib Abd Rashid, Mohd Rofdzi Abdullah, Dzulkarnaen Ismail, Mohd Hafiz Saberi

To Link this Article: http://dx.doi.org/10.6007/IJARBSS/v11-i2/9202

DOI:10.6007/IJARBSS/v11-i2/9202

Received: 10 December 2020, Revised: 11 January 2021, Accepted: 25 January 2021

Published Online: 22 February 2021

In-Text Citation: (Rashid et al., 2021)

To Cite this Article: Rashid, M. N. A., Abdullah, M. R., Ismail, D., \& Saberi, M. H. (2021). Success Criteria for Automation and Robotics in Industrialised Building System (IBS). International Journal of Academic Research in Business and Social Sciences, 11(2), 1259-1273.

Copyright: (c) 2021 The Author(s)

Published by Human Resource Management Academic Research Society (www.hrmars.com)

This article is published under the Creative Commons Attribution (CC BY 4.0) license. Anyone may reproduce, distribute, translate and create derivative works of this article (for both commercial and non-commercial purposes), subject to full attribution to the original publication and authors. The full terms of this license may be seen at: http://creativecommons.org/licences/by/4.0/legalcode

Vol. 11, No. 2, 2021, Pg. 1259 - 1273

Full Terms \& Conditions of access and use can be found at http://hrmars.com/index.php/pages/detail/publication-ethics 


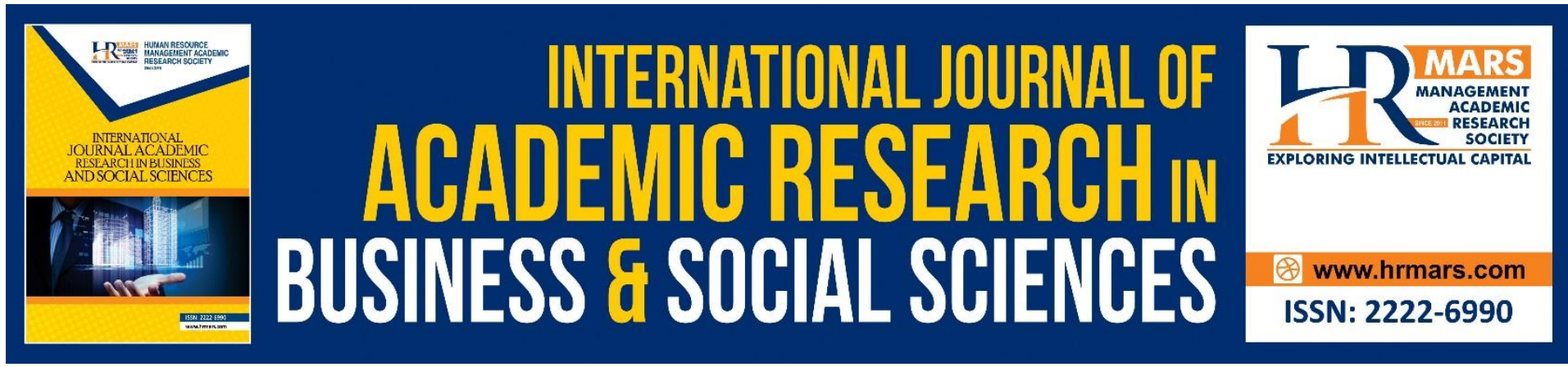

\title{
Success Criteria for Automation and Robotics in Industrialised Building System (IBS)
}

\author{
${ }^{1}$ Mohd Najib Abd Rashid, ${ }^{2}$ Mohd Rofdzi Abdullah, ${ }^{2}$ Dzulkarnaen \\ Ismail, ${ }^{3}$ Mohd Hafiz Saberi \\ ${ }^{1}$ Institute of Postgraduate Studies, Universiti Teknologi MARA Perak Branch, \\ 32610 Bandar Seri Iskandar, Perak, Malaysia, ${ }^{2}$ Department of Building, Universiti Teknologi \\ MARA Perak Branch, 32610, Bandar Seri Iskandar, Perak, Malaysia, ${ }^{3}$ Department of Quantity \\ Surveyor, UniversitiTeknologi MARA Perak Branch, 32610 Bandar Seri Iskandar, Perak, \\ Malaysia
}

\begin{abstract}
Automation and robotics in the Industrialised Building System (IBS) hold much promise for the Malaysian construction industry to move towards the fourth industrial revolution. Previous studies lacked in-depth exploration of stakeholder perception for measuring automation and robotics success within the industry. This paper examined the stakeholder perception of success criteria for measuring automation and robotics in IBS. The study was conducted through a questionnaire survey with wide-ranging IBS stakeholder that yielded two-hundred and one (201) effective response. A total of nineteen (19) success criteria for measuring automation and robotics in IBS were analysed through exploratory factor analysis, mean score and ANOVA. The findings reveal that reduce construction time, reduce production time, reduce waste, reduce material consumption, and improved occupational safety and health are the most important criteria for measuring automation and robotics in IBS. This paper contributes to the literature of automation and robotics in IBS and providing new insights for future research and development.
\end{abstract}

Keywords: Success Criteria, Automation and Robotics, Industrialised Building System.

\section{Introduction}

As a developing country, Malaysia depends on the construction industry to provide employment opportunities and enhance its economic development. However, several problems need to overcome to improve industry productivity (Yunus et al., 2016). The previous researcher highlighted that this industry has a poor record for project success in cost, quality, safety and time completion. One of the promising solutions was the introduction of industrialised building system (IBS). However, the issues of quality of the overall finished work, less productive, more costly, and cause the delay of the project had hampered the implementation of IBS (Hung et al., 2015; Mohamed et al., 2019, 2018). Hence, a move towards automation and robotics in IBS was the only way for IBS to progress in the industry (Rashid et al., 2018). Automation and robotics are categories as smart machines or smart devices that are programmable to execute tasks automatically, creating a wide range of 
research topics in both well-engineered industrial workplaces and domain-oriented applications operating in dangerous or harsh environments (Mahbub, 2015; Pan \& Pan, 2020; Saidi et al., 2016). The implementation of automation and robotics in IBS also includes the incorporation of related technologies and systems, such as smart sensing systems, building information modelling (BIM), Internet of things (IOT), virtual reality (VR) and artificial intelligence, which have now been widely promoted to reshape the construction industry (Linner \& Bock, 2012; Rashid et al., 2018a, 2018b; Saidi et al., 2016).

A lot of research has been conducted to prove the reliability of automation and robotics in IBS. Richard (2005) introduces the concept of reproduction for IBS that seeks innovative processes capable of shortcutting the repetitive linear operations of craftsmanship. Qiu (2007) develop RFID-enabled automation in support of factory integration to improve productivity on the shop floor relies on efficient and accurate information flow from process to process, from shop floor to shop floor, and from manufacturer to manufacturer. Son et al. (2010) conducted a detail trend analysis of research and development in automation and robotics. They summarized four (4) categories: planning and design, construction robotics, intelligent job-site management and operation and maintenance. All these categories were intended to improved productivity of IBS construction. Mahbub (2012) conducted a study on the readiness of automation and robotics in the Malaysian construction industry and concluded that the industry is ready to a certain degree to embrace the technologies in limited areas such as prefabrication and assembly the design, planning and costing phases. Kehoe et al. (2015) surveyed application of cloud robotics and automation for data processing and information exchange remotely with access to dynamic global datasets to support various functions. Kasperzyk et al. (2017) develop a new approach of an automated re-prefabrication system that introduces a robotics-based prefabrication system called RPS to increase the design flexibility of current IBS production practice. Ilhan et al. (2018) discussed automation and robotics technology to achieve success toward sustainability. Rashid et al. (2018a) examined the critical success factors for automation and robotics in IBS. Yang et al. (2019) has developed a new theory of 'co-evolution through interaction' modular integrated construction robotics. However, previous studies lacked in-depth exploration of stakeholder perception for measuring automation and robotics success within the industry. Hence, this paper aims to determine the most critical success criteria for measuring the success of automation and robotics in IBS.

\section{Success Criteria for measuring Automation and Robotics in IBS}

Wai et al. (2012) defined success criteria as a principle or standard by which something may be judged or decided. Moreover, the success criteria should be observable and measurable. It is worth noting that success criteria differ from success factors because success criteria are the variables used to measure success, whilst success factors are efforts to reach predetermined objectives. This statement was in line with Korbijn (2014) as he defines success criteria are the set of principles, standards or measures used to judge the success or failure. These are the dependent variables that measure success. Success criteria answer the question: how do you determine if a project is successful and with the context of this study how we assess the success of automation and robotics in IBS.

Automation and robotics are increasingly recognised as the most promising solutions to address the multifaceted challenges confronting the construction industry and as advanced 
techniques to underpin buildings' production (Pan et al., 2020). According to Kapliński et al. (2002) mechanisation, automation and robotics significantly increase work efficiency with improvement in working conditions, the safety of the builders and progress in the quality of work done or product. Another aspect that could be taken into account is the cost reduction, mostly due to the decrease in workload per task, and eliminating or cutting down the need to use scaffolding, security system and additional transport equipment. On top of that, a study conducted by Cobb (2001) ranks the outcome of using automation and robotics technologies in construction, which is productivity improvements, improvement in quality and reliability, improving safety, improvement in working conditions, savings on labour costs, standardisation of components, overall whole-life cost savings, simplifying operations, and shortage of workforce. Besides, Kamaruddin et al. (2016) had also listed other impacts of automation in construction which are: improvement of productivity, quality stability, short construction period, and a high degree of design freedom, improvement of the construction environment, safety parameters, reduction of debris and overall cost reduction.

Automation and robotics have been progressing to reduce the time and cost of operation. For instance, lowering the cost could be done by replacing human workers with robots. Apart from the economic aspect, construction robotics has technical features to enhance the operations' quality and efficiency (Ardiny et al., 2015). Moreover, robots could potentially perform construction tasks where human presence is impossible, undesirable, or unsafe, for instance, construction in hazardous areas after natural or human-made disasters such as earthquakes and nuclear accidents, construction under difficult physical conditions such as undersea or outer space locations, and construction in areas that are not readily accessible to humans or that require an initial structure to prepare the environment for human arrival (Rashid et al., 2018). Moreover, Son et al. (2010) stated that automation and robotics improved productivity and efficiency make construction more affordable. Besides, the use of automation and robotics technology spurs market growth through the provision of new or improved products and services as well as reductions in the cost of production. Also, the extent of the harmful environmental effects of construction-related activities is reduced by adopting improved components and technologies. Lim et al. (2012) stated that several drivers are pushing construction towards automation and robotics in IBS, reducing labour, improved safety, reducing construction time on site, reducing production costs, and increasing architectural freedom. In his study, Waris \& Khamidi (2013) suggested that by adopting mechanisation, automation and robotics will constitute reducing construction time, enhance productivity, quality, efficiency, and high-class quality. Abanda et al. (2017) stated that automation and robotics improved quality, good health and safety, better working conditions, higher tolerances, lower costs, reduced labour re-works, lower construction waste, and simplified construction processes. These products are factory tried and tested, predictable sustainability performance, better control and consistency in products and processes.

On top of that, the adoption of automation and robotics has demonstrated multiple benefits including a substantial reduction of waste, significant time saving, flexible working conditions, improved quality, Affordability, Improved productivity and Improved safety Pan et al. (2018a). Increased client satisfaction towards the product quality also measured success criteria for automation and robotics in IBS (Yunus et al., 2016, 2015). The introduction of automation and robotics in IBS has undoubtedly impacted the industry, but so far it has not 
achieved the level of the technology adopted by developed countries (Rashid et al., 2018; Kamaruddin et al., 2013). To conclude, automation and robotics offer many benefits to the Malaysian construction industry's betterment. However, many aspects of our industry still have much room for improvements. Measuring automation and robotics in IBS will improve the industry and fulfil the government's target to move towards the 4th Industrial revolution (Rashid et al., 2019). Table 1 summarised the success criteria for measuring automation and robotics success in IBS.

Table 1. Success Criteria for Automation and Robotics in IBS

\begin{tabular}{|c|c|c|c|}
\hline $\begin{array}{l}\mathbf{N} \\
\mathbf{0}\end{array}$ & Success Criteria & References & $\begin{array}{l}\text { Tot } \\
\text { al }\end{array}$ \\
\hline 1 & Client Satisfaction & [5] [6] [10] [16] & 4 \\
\hline 2 & High Quality Product & $\begin{array}{l}{[1][2][3][5][7][11][12][13][16][17][18]} \\
{[19]}\end{array}$ & 12 \\
\hline 3 & $\begin{array}{l}\text { Improved Occupational Safety } \\
\text { \& Health }\end{array}$ & $\begin{array}{l}{[1][2][3][5][7][8][11][12][13][14][18]} \\
{[19]}\end{array}$ & 12 \\
\hline 4 & Higher Productivity & [1] [2] [5] [7] [10] [12] [16] [18] [19] & 9 \\
\hline 5 & Reducing Production Time & [5] [13] [18] [19] & 4 \\
\hline 6 & Reduction of labor workforce & [2] [5] [8] [14] [16] [18] [19] & 7 \\
\hline 7 & Reduce Overall Cost & $\begin{array}{l}{[1][2][3][5][7][8][11][12][13][14][16]} \\
{[17][18][19]}\end{array}$ & 14 \\
\hline 8 & Reduce Construction Time & $\begin{array}{l}{[1][5][8][10][12][13][14][16][17][18]} \\
{[19]}\end{array}$ & 11 \\
\hline 9 & $\begin{array}{l}\text { Improvement of working } \\
\text { Condition }\end{array}$ & [1] [2] [3] [5] [11] [12] [13] [18] [19] & 9 \\
\hline $\begin{array}{l}1 \\
0\end{array}$ & Waste Reduction & [16] [17] [18] [19] & 4 \\
\hline $\begin{array}{l}1 \\
1\end{array}$ & Material Recycling & [9] [19] & 2 \\
\hline $\begin{array}{l}1 \\
2\end{array}$ & Saving in Material Consumption & [9] [19] & 2 \\
\hline $\begin{array}{l}1 \\
3\end{array}$ & Employee Satisfaction & [6] [18] [19] & 3 \\
\hline $\begin{array}{l}1 \\
4\end{array}$ & Technology validity & [4] [6] [19] & 3 \\
\hline $\begin{array}{l}1 \\
5\end{array}$ & Technology Reliability & [4] [19] & 2 \\
\hline $\begin{array}{l}1 \\
6\end{array}$ & Ease of Use & [15] [19] & 2 \\
\hline $\begin{array}{l}1 \\
7\end{array}$ & Technology Flexibility & [3] [4] [12] [15] [19] & 5 \\
\hline $\begin{array}{l}1 \\
8\end{array}$ & Technology Availability & [4] [6] [19] & 3 \\
\hline $\begin{array}{l}1 \\
9\end{array}$ & Technology Acceptability & [4] [6] [19] & 3 \\
\hline
\end{tabular}

Note: [1] Wakisaka et al. (2000); [2] Cobb (2001); [3] Kapliński et al. (2002); [4] Dunmade (2002); [5] (Kumar et al. (2008); [6] Mahbub (2008); [7] Neelamkavil (2009); [8] Lim et al. 
(2012); [9] Lachimpadi et al. (2012); [10] Waris \& Khamidi (2013); [11] Ardiny et al. (2015); [12] Kamaruddin et al. (2016); [13] Silva et al. (2016); [14] (Hanafi et al. (2016); [15] Bock \& Linner (2017); [16] Boafo et al. (2016); [17] Mohammad et al. (2016); [18] Abanda et al. (2017); [19] Pan et al. (2018a)

\section{Methodology}

A quantitative method was adopted in this research, and questionnaires were distributed to the companies in Kuala Lumpur and Selangor. The Questionnaires were distributed using Google forms which can help the researcher collect the information quickly. The questionnaire was first pre-tested to 6 experts on the field for comments and suggestion. Then the questionnaire was pilot to 30 respondents for its reliability. The questionnaires were sending randomly based on the company's email. A total of 1183 sets of questionnaires were distributed to the respondents consisting of IBS contractor, IBS consultant dan IBS manufacturer from August 2019 until November 2019 of which, 210 were returned with 201 usable formats. A seven-point Likert scale was used to determine the level of agreement of the criteria for measuring automation and robotics in IBS. The adopted scale was as follows: 1=Strongly Disagree and, 7=Strongly agree.

The quantitative data were converted using SPSS version 23 software for descriptive and statistical analyses. Exploratory factor analysis (EFA) was conducted using the principal component method with varimax rotation on the items of success criteria to reduce the dimensions of the derived factors. There are several criteria and guidelines for EFA to assess the data suitability, factor selection, and reliability (Hair et al., 2014). The measure of sampling adequacy (MSA) or KMO test, which should be higher than 0.5 , and Bartlett's test of sphericity, which should be significant $(p<0.05)$, were conducted to assess the suitability of the collected data for EFA. Items with communality higher than 0.5 and factor loading greater than \pm 0.50 but not cross-loaded significantly were considered practically significant. The reliability of the extracted factors was assessed by Cronbach's $\alpha$, with a satisfactory value was considered to be above 0.7 (Hair et al., 2014).

The standard deviations were calculated to illustrate the respondents' degree of difference. The mean score method is used to explore the importance of the criteria. If two or more criteria have the same mean score, the one with the lower standard deviation (SD) is assigned a higher rank (Jiang et al., 2018; Ojoko et al., 2018). Nevertheless, this mean score value (Pan et al., 2020; Yunus et al., 2017) was used for ranking variables or items. A higher mean value indicates higher perceived importance of the survey participants about the target item. The ANOVA tests were then applied to assess the statistical consistency of the perceptions from different stakeholder groups. When the $p$-value of ANOVA is smaller than 0.05 , there is a statistically significant difference among the different groups. When the $p$ value of ANOVA is larger than 0.05, there is no statistically significant difference among different groups (Jiang et al., 2018).

\section{Results and Discussion}

\section{Background Information of Respondents}

The profiles of the questionnaire survey participants are summarised in Fig. 1. Through their primary organisational affiliations, the participants effectively covered the three key stakeholder groups related to the use of automation and robotics in the industrialised 
building system. The groups were (1) contractors (including main contractor and subcontractor) (72\%); (2) consultant (16\%); and (3) manufacturer (12\%). More than $50 \%$ of the questionnaire participants had more than ten years of experience. More than $70 \%$ of questionnaire participants were from the management level, which ensured good-quality, reliable data about how automation and robotics in IBS have been used and perceived.
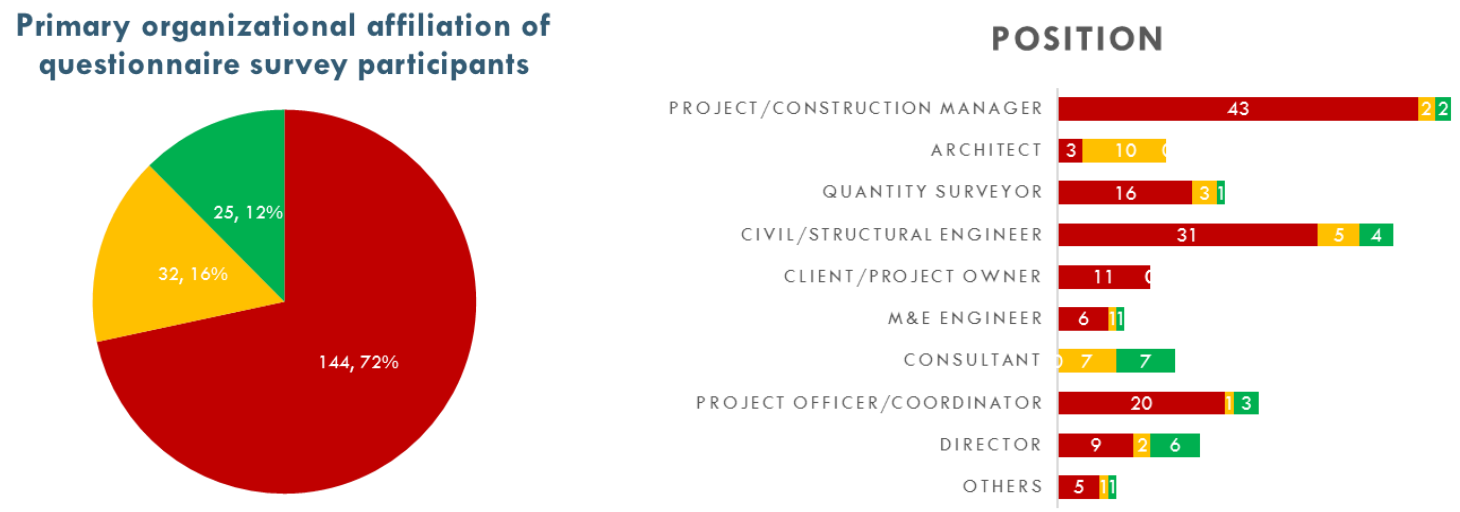

YEARS OF WORK EXPERIENCE

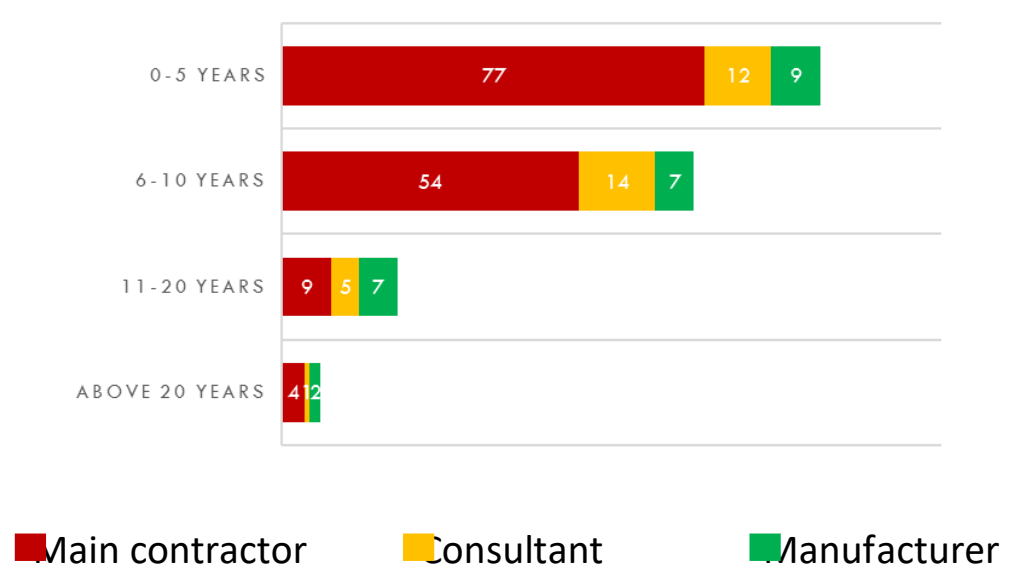

Figure 1. Primary organisational affiliation, work experience and position of questionnaire survey participants $(n=201)$

\section{Exploratory factor analysis of the success criteria for measuring automation and robotics in IBS}

Before conducting EFA, the Cronbach's $\alpha$ was checked and produced a value of 0.958 for the whole scale, and was over 0.7, indicating acceptable reliability (Hair et al., 2014). Cronbach's Alpha reliability test was conducted to determine the reliability of each respondent's responses to the success criteria listed in the questionnaire. The Kaiser-MeyerOlkin (KMO) measure of sampling adequacy achieved a value of 0.940 , exceeding the recommended minimum value of 0.6 . Bartlett's test of sphericity was also statistically significant (less than 0.05 ) with a value of 0.000 , thus supporting the correlation matrix's factorability, as shown in Table 2 . Therefore, factor analysis could be used for this study. The second step is communalities, which shown in Table 3, after the third run, sixteen (16) assessed factors have communalities figures of above 0.5. Following the data's suitability, factor analysis was conducted using principal component analysis (PCA) with varimax 
rotation. A screen plot was used to determine which components to extract and retain. Table 4 shows one (1) component with eigenvalues greater than one (1) that were extracted. The total variance explained by the component extracted is 63.24 per cent. Table 5 shows the extracted components and the variables loading on them. Components with 0.5 and above are recognised as important (Hair et al., 2014).

Table 2. KMO and Bartlett's test for Success Criteria

\begin{tabular}{lrr}
\hline \multicolumn{2}{c}{ KMO and Bartlett's Test } \\
\hline Kaiser-Meyer-Olkin Measure of Sampling Adequacy. & 0.940 \\
\hline Bartlett's Test of Sphericity & Approx. Chi-Square & 3242.435 \\
& df & 171 \\
& Sig. & 0.000 \\
\hline
\end{tabular}

Table 3. Communalities

\begin{tabular}{|c|c|c|c|c|c|}
\hline Code & Success Criteria & Initial & $1^{\text {st }}$ Run & $2^{\text {nd }}$ Run & $3^{\text {rd }}$ Run \\
\hline SAR1 & Reduced cost & 1.000 & .234 & - & - \\
\hline SAR2 & Increased Productivity & 1.000 & .531 & .533 & .539 \\
\hline SAR3 & High-Quality Product & 1.000 & .555 & .553 & .563 \\
\hline SAR4 & Reduced Production Time & 1.000 & .561 & .572 & .584 \\
\hline SAR5 & Reduced construction Time & 1.000 & .598 & .604 & .611 \\
\hline SAR6 & Recycled Waste Material & 1.000 & .587 & .600 & .607 \\
\hline SAR7 & Reduced Material Consumption & 1.000 & .610 & .614 & .627 \\
\hline SAR8 & Workforce Reduction & 1.000 & .624 & .638 & .649 \\
\hline SAR9 & Improved Occupational Safety and Health (OSH) & 1.000 & .608 & .617 & .618 \\
\hline SAR10 & Reduced Waste & 1.000 & .613 & .623 & .632 \\
\hline SAR11 & Improved Working Condition & 1.000 & .630 & .635 & .633 \\
\hline SAR12 & Employee Satisfaction & 1.000 & .654 & .653 & .650 \\
\hline SAR13 & Client Satisfaction & 1.000 & .681 & .684 & .685 \\
\hline SAR14 & Valid Technology & 1.000 & .714 & .727 & .723 \\
\hline SAR15 & Reliable Technology & 1.000 & .702 & .704 & .690 \\
\hline SAR16 & User-Friendly Technology & 1.000 & .654 & .652 & .633 \\
\hline SAR17 & Technology Flexibility & 1.000 & .693 & .684 & .672 \\
\hline SAR18 & Technology Availability & 1.000 & .385 & - & - \\
\hline SAR19 & Technology Acceptance & 1.000 & .508 & 0.480 & - \\
\hline
\end{tabular}


Table 4. Total Variance Explained

\begin{tabular}{|c|c|c|c|c|c|c|}
\hline \multirow{2}{*}{ Component } & \multicolumn{3}{|c|}{ Initial Eigenvalues } & \multicolumn{3}{|c|}{$\begin{array}{l}\text { Extraction Sums of Squared } \\
\text { Loadings }\end{array}$} \\
\hline & Total & $\begin{array}{c}\% \text { of } \\
\text { variance }\end{array}$ & $\begin{array}{c}\text { Cumulative } \\
\%\end{array}$ & Total & $\begin{array}{c}\% \text { of } \\
\text { variance }\end{array}$ & $\begin{array}{c}\text { Cumulative } \\
\%\end{array}$ \\
\hline 1 & 10.118 & 63.236 & 63.236 & 10.118 & 63.236 & 63.236 \\
\hline$\downarrow$ & $\downarrow$ & $\downarrow$ & $\downarrow$ & & & \\
\hline 14 & .169 & 1.056 & 98.335 & & & \\
\hline 15 & .138 & .863 & 99.199 & & & \\
\hline 16 & .128 & .801 & 100.000 & & & \\
\hline
\end{tabular}

Extraction Method: Principal Component Analysis.

Table 5. Rotated Component Matrix

\begin{tabular}{llc}
\hline & & \\
Success & Criteria for Automation and robotics in IBS & Component \\
\cline { 3 - 3 } & & SAR \\
\hline SAR2 & Increased Productivity & .734 \\
SAR3 & High-Quality Product & .750 \\
SAR4 & Reduced Production Time & .764 \\
SAR5 & Reduced construction Time & .781 \\
SAR6 & Recycled Waste Material & .779 \\
SAR7 & Reduced Material Consumption & .792 \\
SAR8 & Workforce Reduction & .806 \\
SAR9 & Improved Occupational Safety and Health (OSH) & .786 \\
SAR10 & Reduced Waste & .795 \\
SAR11 & Improved Working Condition & .796 \\
SAR12 & Employee Satisfaction & .806 \\
SAR13 & Client Satisfaction & .828 \\
SAR14 & Valid Technology & .850 \\
SAR15 & Reliable Technology & .830 \\
SAR16 & User-Friendly Technology & .796 \\
SAR17 & Technology Flexibility & .820 \\
\hline
\end{tabular}

Extraction Method: Principal Component Analysis.

a. 1 components extracted.

\section{Ranking of Success Criteria for Measuring Automation and Robotics in IBS}

The study then evaluated the perceived success criteria in different contexts that could measure the success of automation and robotics in IBS. Nineteen (19) influencing factors were identified by reviewing the literature and documents in automation and robotics-related to IBS (Rashid et al., 2019). The results are presented in Table 6. According to the mean values, all the success criteria were considered influential (with mean values larger than 5) for measuring automation and robotic in IBS in Malaysia. Notably, reduced construction time was ranked the highest criteria by all stakeholder. It attracted a mean score value of (5.79). The finding agrees with (Linner \& Bock, 2012; Saidi et al., 2016) as the 
components and module need a just in time delivery for onsite installation, resulting in reduced project completion time. Reduce production time (5.69) was perceived to have the second-highest influence on measuring automation and robotics success in IBS. This rating aligns with the remark of (Linner \& Bock, 2012; Saidi et al., 2016). A significant reason is that from conception to manufacturing, the whole process is aid by the automation and robotics technology. The high degree of information and communication ICT, the integration of devices by the internet of things (IOT) and, utilisation of CAD/CAM systems supported by building information modelling or applicable ERP system has made the production time reduce significantly (Rashid et al., 2018; Johansson et al., 2015; Niccolini et al., 2018).

Waste reduction was rated third, and it attracts a mean score value of (5.67). The finding is consistent with the previous researcher (Hamid et al., 2012; Pan et al., 2018b). The use of robotic technology in IBS production has also resulted in a consistent quality of products and less waste in factories, due to computer-assisted planning and programming, only the necessary amount of concrete is being provided from the batching plant (Ilhan et al., 2018; Vähä et al., 2013; Yin et al., 2019). Fourthly, reducing material consumption was considered an influential success criterion with a mean score value (5.66). The finding concurs with (Bock \& Linner, 2015; Pan et al., 2018b). Generally, the machine can do the job more precisely and efficiently. Automated approaches can catalyse the efficient use of materials in many ways. For instance, the optimisation of resource utilisation can be achieved by systematic scheduling and automation in IBS factories under dynamic circumstances. Sensorbased control can track the material and components for better interactions and detect the geometry of waste component for reuse (Neelamkavil, 2009). Fifthly, improved occupational health and safety received a mean score value (5.66). In this regard, machines can replace human workers in these hazardous, dull, dangerous, and dirty tasks and reduce injuries and fatalities.

Additionally, equipped with automation and robotics, negative impacts of construction work on human labours' health can be mitigated by vastly reducing dangerous physical works and providing better physical working conditions (Linner \& Bock, 2012; Pan et al., 2018b). Although the 'reduced construction time', 'reduce production time', 'reduced waste', reduce material consumption' and, 'improved occupational safety and health' success criteria has the highest mean score and rated as top five, the other success criteria should not be taken lightly. All the sixteen (16) success criteria which show a mean score value above (5.00) indicates that they are also essential criteria for measuring automation and robotics in IBS. On the other hand, the ANOVA test results showed no significant difference between different stakeholder groups. These findings indicate that the various stakeholders' opinions generally were not statistically significantly different from each other, means that a mutual consensus on the agreement of the criteria for measuring automation and robotics was achieved. 
Table 6: Importance of Success Criteria for Measuring Automation and Robotics in IBS

\begin{tabular}{|c|c|c|c|c|c|c|}
\hline \multicolumn{2}{|c|}{$\begin{array}{l}\text { Success Criteria of Automation and } \\
\text { Robotics in IBS }\end{array}$} & \multirow{2}{*}{$\begin{array}{c}\text { Mean } \\
5.79\end{array}$} & \multirow{2}{*}{$\begin{array}{c}\begin{array}{c}\text { Std. } \\
\text { Deviation }\end{array} \\
1.072\end{array}$} & \multirow{2}{*}{$\frac{\text { Rank }}{1}$} & \multirow{2}{*}{$\begin{array}{c}\begin{array}{c}\text { ANOVA } \\
\text { significance }\end{array} \\
0.877\end{array}$} & \multirow{2}{*}{$\begin{array}{c}\begin{array}{c}\text { Factor } \\
\text { Loading }\end{array} \\
0.781\end{array}$} \\
\hline SAR5 & Reduced construction Time & & & & & \\
\hline SAR4 & Reduced Production Time & 5.69 & 1.013 & 2 & 0.668 & 0.764 \\
\hline SAR6 & Reduced Waste & 5.67 & 1.021 & 3 & 0.483 & 0.779 \\
\hline SAR7 & $\begin{array}{l}\text { Reduced Material } \\
\text { Consumption }\end{array}$ & 5.66 & 1.061 & 4 & 0.720 & 0.792 \\
\hline SAR9 & $\begin{array}{l}\text { Improved Occupational Safety } \\
\text { and Health (OSH) }\end{array}$ & 5.66 & 1.089 & 5 & 0.426 & 0.786 \\
\hline SAR11 & Improved Working Condition & 5.65 & 1.004 & 6 & 0.480 & 0.796 \\
\hline SAR2 & Increased Productivity & 5.64 & 1.059 & 7 & 0.781 & 0.734 \\
\hline SAR6 & Recycled Waste Material & 5.62 & 1.134 & 8 & 0.483 & 0.779 \\
\hline SAR8 & Workforce Reduction & 5.61 & 1.118 & 9 & 0.257 & 0.806 \\
\hline SAR3 & High Quality Product & 5.60 & 1.123 & 10 & 0.818 & 0.750 \\
\hline SAR14 & Valid Technology & 5.59 & 1.055 & 11 & 0.622 & 0.850 \\
\hline SAR15 & Reliable Technology & 5.57 & 1.071 & 12 & 0.666 & 0.830 \\
\hline SAR13 & Client Satisfaction & 5.54 & 1.095 & 13 & 0.530 & 0.828 \\
\hline SAR16 & User Friendly Technology & 5.48 & 1.205 & 14 & 0.270 & 0.796 \\
\hline SAR17 & Technology Flexibility & 5.46 & 1.100 & 15 & 0.705 & 0.820 \\
\hline SAR12 & Employee Satisfaction & 5.45 & 1.024 & 16 & 0.728 & 0.806 \\
\hline
\end{tabular}

\section{Conclusion}

Automation and robotics in IBS are undoubtedly the future of the Malaysian construction industry. However, there is a lack of studies on the success criteria for measuring automation and robotics in IBS. This paper investigated IBS stakeholders' perspectives on the success criteria for measuring automation and robotics in IBS. Nineteen (19) success criteria for measuring automation and robotics were identified through a literature review. Two-hundred and one (201) valid questionnaire were collected. Exploratory factor analysis (EFA) was conducted, three (3) items were deleted due to low communalities, leaving sixteen criteria to further analysed using mean score method to establish the critical criteria. Findings reveal that the top five (5) criteria for measuring automation and robotics in IBS are reduced construction time, reduced production time, reduced waste, reduced material consumption, and improved occupational safety and health. Test of ANOVA also reveals no statistical difference among the IBS stakeholder, which means that there was an agreement of the success criteria among the IBS stakeholder.

\section{Acknowledgement}

The authors wish to acknowledge the Institute of Postgraduate Studies (IPS) and the Universiti Teknologi MARA Perak Branch for providing the necessary research facilities and supervision.

\section{Corresponding Author}

Mohd Najib Abd Rashid

Institute of Postgraduate Studies, Universiti Teknologi MARA Perak Branch, 32610 Bandar Seri Iskandar, Perak, Malaysia.

Email: mohdn613@uitm.edu.my 


\section{References}

Abanda, F. H., Tah, J. H. M., \& Cheung, F. K. T. (2017). BIM in off-site manufacturing for buildings. Journal of Building Engineering, 14(March), 89-102.

Ardiny, H., Witwicki, S., \& Mondada, F. (2015). Construction automation with autonomous mobile robots: A review. In Proceedings of the 3rd RSI International Conference on Robotics and Mechatronics, ICROM 2015 (pp. 418-424).

Boafo, F. E., Kim, J. H., \& Kim, J. T. (2016). Performance of modular prefabricated architecture: Case study-based review and future pathways. Sustainability (Switzerland), 8(6), 1-16.

Bock, T., \& Linner, T. (2015). Robotic Industrialization: Automation and Robotic Technologies for Customized Component, Module, and Building Prefabrication. Cambridge University Press.

Bock, T., \& Linner, T. (2017). Construction Robots: Elementary Technologies and Single-Task Construction Robots. Cambridge University Press.

Cobb, D. W. (2001). Integrating automation into construction to achieve performance enhancements. CIB World Building Congress, (April), 1-11.

Dunmade, I. (2002). Indicators of sustainability: assessing the suitability of a foreign technology for a developing economy, 24, 461-471.

Hair, J. F., Black, W. C., Babin, B. J., \& Anderson, R. E. (2014). Multivariate Data Analysis (7th Edition). Pearson.

Hamid, Z. A., \& Kamar, K. A. M. (2012). Aspects of off-site manufacturing application towards sustainable construction in Malaysia. Construction Innovation, 12(1), 4-10.

Hanafi, M. H., Abas, A., Ibrahim, F. A., \& Abdullah, S. (2016). Readiness for industrialized building system implementation among Malaysian architectural firms' members. Jurnal Teknologi, 78(7), 195-203.

Hung, F. C., Hamid, Z. A., Din, M. I., \& Norman, M. R. (2015). Study on industrialised building system (IBS) adoption level and contractors' readiness in Malaysia 2013. Malaysian Construction Research Journal, 17(1), 1-19.

Ilhan, B., Hu, R., Iturralde, K., Pan, W., Taghavi, M., \& Bock, T. (2018). Achieving Sustainability in Construction Through Automation and Robotics. Grand Renewable Energy 2018, 17(March).

Jiang, L., Li, Z., Li, L., \& Gao, Y. (2018). Constraints on the Promotion of Prefabricated Construction in China. Sustainability (MDPI), 1-17.

Johansson, M., Roupé, M., \& Bosch-sijtsema, P. (2015). Automation in Construction Real-time visualization of building information models ( BIM ). Automatization in Construction, 54, 69-82.

Kamaruddin, S. S., Mohammad, M. F., \& Mahbub, R. (2016). Barriers and Impact of Mechanisation and Automation in Construction to Achieve Better Quality Products. Procedia - Social and Behavioral Sciences, 222, 111-120.

Kamaruddin, S. S., Mohammad, M. F., Mahbub, R., \& Ahmad, K. (2013). Mechanisation and Automation of the IBS Construction Approach: A Malaysian Experience. Procedia-Social and Behavioral Sciences, 105, 106-114.

Kapliński, O., Werner, W., Kosecki, A., Biernacki, J., \& Kuczmarski, F. (2002). Current state and perspectives of research on construction management and mechanisation in Poland. Journal of Civil Engineering and Management, 8(4), 221-230.

Kasperzyk, C., Kim, M. K., \& Brilakis, I. (2017). Automated re-prefabrication system for buildings using robotics. Automation in Construction, 83(July), 184-195.

Kehoe, B., Patil, S., Abbeel, P., \& Goldberg, K. G. (2015). A Survey of Research on Cloud 
Robotics and Automation. IEEE Transactions on Automation Science and Engineering, 12(2), 398-409.

Korbijn, G. (2014). Success criteria and critical success factors for contractors of urgent and unexpected projects A multiple case study within the maintenance \& repair sector Master thesis October 2014.

Kumar, V. S. ., Prasanthi, I., \& Leena, A. (2008). Robotics and Automation in Construction. Building Integration Solutions.

Lachimpadi, S. K., Pereira, J. J., Taha, M. R., \& Mokhtar, M. (2012). Construction waste minimisation comparing conventional and precast construction (Mixed System and IBS) methods in high-rise buildings: A Malaysia case study. Resources, Conservation and Recycling, 68, 96-103.

Lim, S., Buswell, R. A., Le, T. T., Austin, S. A., Gibb, A. G. F., \& Thorpe, T. (2012). Developments in construction-scale additive manufacturing processes. Automation in Construction, 21(1), 262-268.

Linner, T., \& Bock, T. (2012). Evolution of large-scale industrialisation and service innovation in Japanese prefabrication industry. Construction Innovation, 12(2), 156-178.

Mahbub, R. (2008). An investigation into the barriers to automation and robotics technologies in the construction industry. PhD Thesis.

Mahbub, R. (2012). The readiness of a Developing Nation in Implementing Automation and Robotics Technologies in Construction: A Case Study of Malaysia. Journal of Civil Engineering and Architecture, 6(7), 858-866.

Mahbub, R. (2015). Framework on the Barriers to the Implementation of Automation and Robotics in the Construction industry. International Journal of Innovation in Management.

Mohamed, M. R., Mohammad, M. F., Mahbub, R., Ramli, M. A., Gunasagaran, S., \& Halim, S. M. A. (2019). Business Strategy of Small and Medium-Sized Enterprise Construction Companies in Adopting Industrialised Building System in Malaysia. International Journal of Academic Research in Business \& Social Science, 9(9), 1127-1139.

Mohamed, M. R., Mohammad, M. F., Mahbub, R., Ramli, M. A., \& Jamal, K. A. A. (2018). The Issues and Challenges of Small and Medium-Sized Contractors in Adopting Industrialised Building System. International Journal of Engineering \& Technology, 7(3.25), 432-436.

Mohammad, M. F., Baharin, A. S., Musa, M. F., \& Yusof, M. R. (2016). The Potential Application of IBS Modular System in the Construction of Housing Scheme in Malaysia. Procedia Social and Behavioral Sciences, 222, 75-82.

Neelamkavil, J. (2009). Automation in the prefab and modular construction industry. International Symposium on Automation and Robotics in Construction ISARC, (Isarc), 2427.

Niccolini, M., Bellissima, A., Argiolas, A., Carra, G., \& Ragaglia, M. (2018). Robotics in the Construction Industry: State of the Art and Future Opportunities. Proceedings of the 35th International Symposium on Automation and Robotics in Construction (ISARC), (Isarc).

Ojoko, E. O., Osman, M. H., Abdul Rahman, A. B., \& Bakhary, N. (2018). Evaluating the Critical Success Factors of Industrialised Building System Implementation in Nigeria: The Stakeholders' Perception. International Journal of Built Environment and Sustainability, $5(2)$.

Pan, M., Linner, T., Pan, W., Cheng, H., \& Bock, T. (2018a). A framework of indicators for assessing construction automation and robotics in the sustainability context. Journal of Cleaner Production, 182, 82-95. 
Pan, M., Linner, T., Pan, W., Cheng, H., \& Bock, T. (2018b). A framework of indicators for assessing construction automation and robotics in the sustainability context. Journal of Cleaner Production, 182(February), 82-95.

Pan, M., \& Pan, W. (2020). Stakeholder Perceptions of the Future Application of Construction Robots for Buildings in a Dialectical System Framework. Journal of Management in Engineering, 36(6), 1-13.

Qiu, R. G. (2007). RFID-enabled automation in support of factory integration. Robotics and Computer-Integrated Manufacturing, 23(6), 677-683.

Rashid, M. N. A., Abdullah, M. R., \& Ismail, D. (2018a). Critical Success Factors CSFs to Automation and Robotics in Industrialized Building System (IBS). International Journal of Academic Research in Business \& Social Science, 8(12), 2207-2221.

Rashid, M. N. A., Abdullah, M. R., \& Ismail, D. (2018b). Key Elements Towards Automation and Robotics in Industrialised Building System (IBS). In Proceedings of the ASEAN Post Graduate Conference (APGC) 2018, University of Malaya, Kuala Lumpur (pp. 152-160).

Rashid, M. N. A., Abdullah, M. R., Ismail, D., \& Mahyuddin, M. N. (2018). Towards Automation And Robotics In Industrialised Building System ( IBS ): A Literature Review. In 3rd International Conference On Rebuilding Place (ICRP 2018). Ipoh, Perak.

Rashid, M. N. A., Abdullah, M. R., Ismail, D., \& Saberi, M. H. (2019). Automation and Robotics in Industrialized Building System (IBS): The Potential Criteria for Measurement. International Journal of Academic Research in Business \& Social Sciences.

Richard, R. B. (2005). Industrialised building systems: Reproduction before automation and robotics. Automation in Construction, 14(4), 442-451.

Saidi, K. S., Bock, T., \& Georgoulas, C. (2016). Robotics in Construction. Springer Handbook of Robotics, 1493-1520.

Silva, G. A. S. K., Warnakulasooriya, B. N. F., \& Arachchige, B. J. H. (2016). Criteria for Construction Project Success: A Literature Review. SSRN Electronic Journal, 697-717.

Son, H., Kim, C., Kim, H., Han, S. H., \& Kim, M. K. (2010). Trend analysis of research and development on automation and robotics technology in the construction industry. KSCE Journal of Civil Engineering, 14(2), 131-139.

Vähä, P., Heikkilä, T., \& Kilpeläinen, P. (2013). Survey on Automation of the Building Construction and Building Products Industry.

Wai, S. H., Yusof, A. M., \& Ismail, S. (2012). Exploring success criteria from the developers' perspective in Malaysia. International Journal of Engineering Business Management, 4(1), 1-9.

Wakisaka, T., Furuya, N., Inoue, Y., \& Shiokawa, T. (2000). Automated construction system for high-rise reinforced concrete buildings. Automation in Construction, 9(3), 229-250.

Waris, M., \& Khamidi, M. F. (2013). Construction Industry Heavy Equipment Acquisition in Malaysian Construction Industry. 2013 IEEE Symposium on Business, Engineering and Industrial Applications, (February 2016).

Yang, Y., Pan, M., \& Pan, W. (2019). Automation in Construction ' Co-evolution through interaction of innovative building technologies: The case of modular integrated construction and robotics. Automation in Construction, 107(May).

Yin, X., Liu, H., Chen, Y., \& Al-hussein, M. (2019). Building information modelling for off-site construction : Review and future directions. Automation in Construction, 101(January), 72-91.

Yunus, R., Abdullah, A. H., Yasin, M. N., Masrom, M. A. N., \& Hanipah, M. H. (2016). Examining performance of Industrialized Building System (IBS) implementation based on contractor 
satisfaction assessment. ARPN Journal of Engineering and Applied Sciences, 11(6), 37763782.

Yunus, R., Masrom, A. N., Abdullah, A. H., \& Mustakim, F. (2015). Conceptual Model of Contractor Satisfaction in the Industrialized Building System (IBS) Implementation. Applied Mechanics and Materials, 773-774, 828-833.

Yunus, R., Noor, S. R. M., Abdullah, A. H., Nagapan, S., Hamid, A. R. A., Tajudin, S. A. A., \& Jusof, S. R. M. (2017). Critical Success Factors for Lean Thinking in the Application of Industrialised Building System (IBS). IOP Conference Series: Materials Science and Engineering, 226, 012045. 